\title{
Energy efficient building block design: An exergy perspective
}

\author{
Yelda Mert ${ }^{\text {a, }}$, Nicel Saygın ${ }^{b}$ \\ a Yüzüncü Yll University, Department of City and Regional Planning, 65080, Van, Turkey \\ b Izmir Institute of Technology, Department of City and Regional Planning, 35100, Urla, Izmir, Turkey
}

\section{A R T I C L E I N F O}

\section{Article history:}

Received 29 November 2015

Received in revised form 16 February 2016

Accepted 20 February 2016

Available online 14 March 2016

\section{Keywords:}

Energy efficient design

Exergy

Urban design

\begin{abstract}
A B S T R A C T
This study introduces the exergy analysis method into the field of urban planning, in order to find out the amount of energy that can be conserved in a building block when an energy efficient construction design is applied. This was done in four steps. First, energy efficient design parameters were derived from the literature and design alternatives were developed accordingly. Second, data was gathered from the case area for the exergy calculations. Third, exergy analysis of existing building blocks and proposed design alternatives were separately carried out. Finally, the amount of decrease in the exergy loss due to suggested energy efficient design was found out. The results show that the exergy efficiency of the existing building blocks is about $2 \%$, while the proposed design alternatives will be around $10-11 \%$. The overall exergy loads of the alternative plans were found as $166.3 \mathrm{~W}, 225.1 \mathrm{~W}, 142.5 \mathrm{~W}$ and $137.8 \mathrm{~W}$ respectively for winter and $105.4 \mathrm{~W}, 140.0 \mathrm{~W}, 89.9 \mathrm{~W}$ and $86.3 \mathrm{~W}$ respectively for summer, on a housing unit basis. As a result, the suitability and importance of the exergy analysis on the built environment was proven, by revealing actual and considerable energy conservation and sustainable use of energy through application of energy efficient design parameters.
\end{abstract}

๑) 2016 Elsevier Ltd. All rights reserved.

\section{Introduction}

In recent years, global environmental problems, increasing population, limited nonrenewable energy sources and global climate changes have emphasized that the connection between energy and environment is very strong and relevant. Furthermore, the cost of energy-whether for the end-users or multinational companies-is another major problem, when the global economic positions of the countries and the companies are taken into account. With these in mind, there are various attempts to decrease energy production costs and reduce emissions for environmental preservation. Attempts to decrease total energy consumption is amongst the major discussions, along with construction of energy efficient devices and systems. In addition to these, cheap, sustainable and renewable energy production is another major study in today's world [21].

When the global energy consumption is investigated for each the sectors, it is seen that $51 \%$ of total energy production is used in industry, $20 \%$ in transportation, $18 \%$ in residential and $12 \%$ in commercial sectors [4]. Globally $50 \%$ of the total energy

\footnotetext{
* Corresponding author. Tel.: +90 5052356033; fax: +90 4322251710.

E-mail address: mertyelda@gmail.com (Y. Mert).
}

consumption and $42 \%$ of the total water consumption take place in the construction and usage period of buildings. Furthermore, $50 \%$ of the greenhouse gases, $40 \%$ of the water pollution and $24 \%$ of the air pollution arises from the activities in the built environment [5]. It is interesting that $81 \%$ of the residential energy demand is used in the heating of buildings [19].

When "energy efficient planning and design" is considered, what comes to mind is basically a relationship of "land use" and "building design" (Fig. 1) [10,16,17]. Energy efficient planning principles systematically investigate a city at three different scales, which are: the settlement's properties, the building block's properties and the building's properties [13]. While making decisions about land use, the ideas to reduce the effects of climate changes should be considered, ensuring efficient and effective use of energy. It is concluded by Ovalı [16] in her study that $50 \%$ of energy consumed in buildings can be conserved in case a climate friendly building and built environment design is applied.

Previous studies have documented investigations of two different scales in the literature from an energy efficiency perspective: building scale and building block scale. Numerous studies have also focused on "physical environment design parameters" and "building design parameters." (Fig. 2) However, there has been relatively little literature published on the use of 


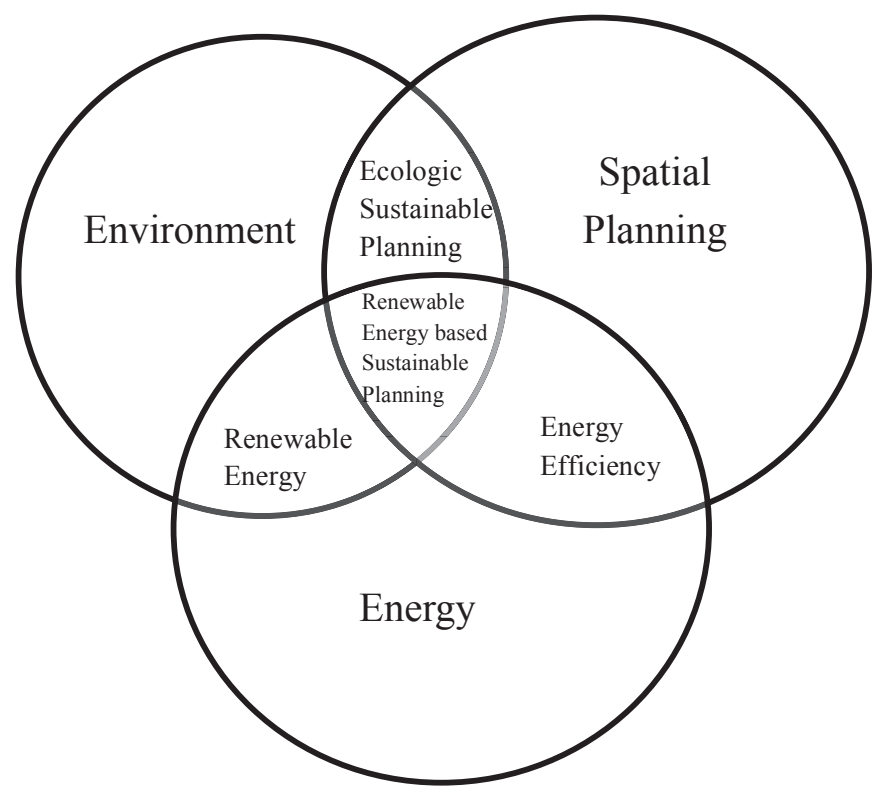

Fig. 1. The relation between planning, environment and energy. (Source: Bayındırlık ve İskan Bakanlığı [2], 766).

renewable energy, such as energy production and conservation based on renewable energy sources.
Much research on exergy focuses on building scale while a great portion of the literature has not utilized all of the parameters that are factors in performance, effectiveness and efficiency of energy in settlement areas.

The studies that only take the building scale parameters into account do not take the relation of the buildings with each other and surrounding environment into account. Only a limited number of studies $[1,3,8,16,18]$ evaluated the energy performance, using only some of the parameters, and they still only conducted a quantitative research.

Furthermore, the studies on exergy related topics which deal with the properties of the buildings and construction materials only focus on building scale, rather than the neighborhood or settlement scales.

Most of the literature efforts did not take the use of renewable energy sources into account and none of them considered local renewable energy resources (solar radiation, wind energy, geothermal and biomass) which should be identified and integrated in the planning policies.

Differing from the literature, this study aims to find out the amount of energy conservation -using exergy analysis in a building block, when "energy efficient design" is applied according to the predefined parameters. In other words, it aims to determine the amount of energy-exergy that can be saved -by means of exergy analysis-for the sake of sustainability when energy efficient design parameters are applied. In addition to the construction materials, orientation and location properties, solar radiation and wind effects are also taken into account in the exergy analysis in this attempt.

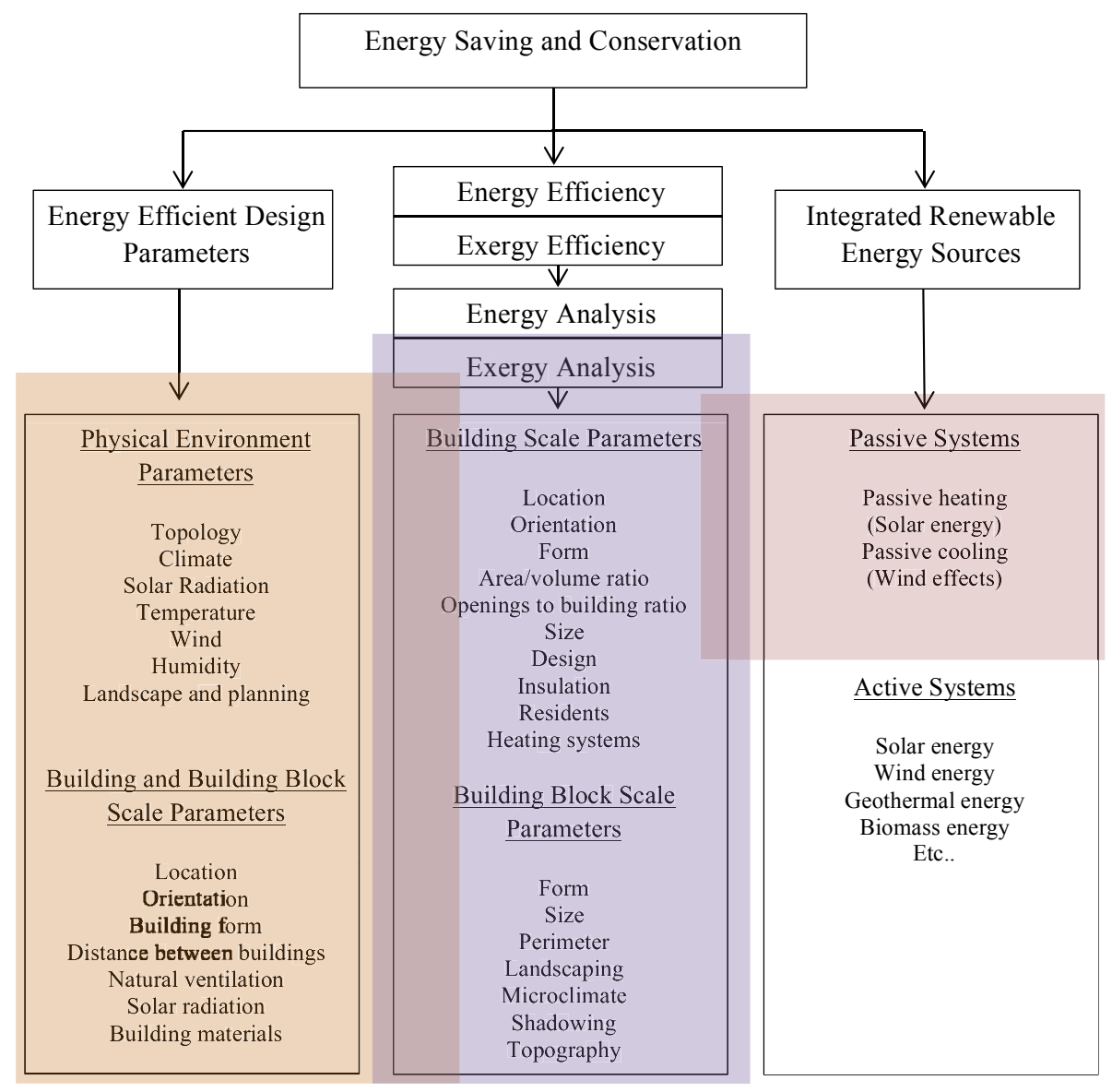

Fig. 2. Structure of the literature. 


\section{Exergy analysis of a residential area}

Calculations for the exergy load of residential building blocks are complicated. This process starts with the data-handling which is composed of some major design parameters of buildings and building blocks which are listed below:

- Building Scale; location of the building, orientation of the building, building form, area/volume ratio of building, openings to building ratio, size of the building, design of the building, insulation of the building, resident information, heating and cooling system properties.

- Building Block Scale; building block form, size of building block, perimeter to area ratio, landscaping and planting of building block, microclimatic properties (wind, average temperature, so on), shadowing due to the configuration of buildings, topography of building block.

After completion of processing and analyzing data, exergy calculations take place:

- Calculation of the Shadow Effect Factor (SEF)

- Calculation of the exergy load of each building for heating and cooling

- Calculation of the exergy loads for the building blocks

This procedure calculates the $\dot{E} x_{\text {demand }}$ that shows us the exergy need of the building. For the calculation of exergy demand, the fundamental procedure (LowEx) proposed by Hepbaşli [6] is used.

$\dot{E} x_{\text {demand }}=\dot{E} x_{\text {loss }}-\dot{E} x_{\text {gain }}$

The procedure follows calculating the losses and gains in the system for reaching exergy demand of the building. Exergy Losses in the building composes of transmission losses during the energy transfer in the building and the ventilation losses that is arisen from the openings of the buildings. Transmission losses through the doors, walls, windows and roofs cause exergy loss $\dot{E} x_{\text {loss }}$;

$\dot{E} x_{\text {loss }}=\dot{E} x_{\text {loss,transmission }}+\dot{E} x_{\text {loss }, \text { ventillation }}$

$\dot{E} x_{\text {loss,transmisson }}=\sum U_{i} \cdot A_{i} \cdot\left(T_{i}-T_{o}\right)$

The transmission losses through the walls, doors, roofs and ceilings are calculated by using necessary the heat transfer coefficient of $\left(\mathrm{U}_{\mathrm{i}}\right)$ as well as the areas $\left(\mathrm{A}_{\mathrm{i}}\right)$ and the indoor $\left(\mathrm{T}_{\mathrm{i}}\right)$ and exterior $\left(\mathrm{T}_{\mathrm{o}}\right)$ air temperature differences into consideration.

$\dot{E} x_{\text {loss }, \text { ventillation }}=C_{p} \rho \cdot V \cdot n_{d} \cdot\left(1-n_{v}\right) \cdot\left(T_{i}-T_{o}\right)$

The loss of exergy through ventilation is calculated using Eq. (4) where $\rho$ and $C_{p}$ are the density $\left[\mathrm{kg} / \mathrm{m}^{3}\right]$ and specific heat $[\mathrm{kj} /$ $\mathrm{kg} \mathrm{K}]$ of air respectively. $n_{d}$ and $n_{v}$ are the air exchange rate [1/h] and the efficiency constants [-], respectively. Also V is the volume of the building unit $\left[\mathrm{m}^{3}\right]$. The ventilation loss is arisen from the openings in the building block such as windows, doors and roofs where the volume of air is transferred in/out to the building block.

Solar gains through the openings in the buildings are the source of Exergy gain $\left(\dot{E} x_{\text {gain }}\right)$ that is a function of SEF (Shadow Effect Factor). Other gains, such as lighting $\left(2 \mathrm{~W} / \mathrm{m}^{2}\right)$, that arises from the auxiliary equipment in the settlements are also taken into account. In order to calculate the gain, the determinations of the facades of the buildings are necessary, since the effect of the orientation of the buildings on the energy and exergy performance of the building depends on it. Each separate building is taken into account in this perspective. Facades that face southwest to southeast and northwest to northeast are also calculated and taken into consideration correspondingly.

$\dot{E} x_{\text {gain }}=\dot{E} x_{\text {gain,solar }}+\dot{E} x_{\text {gain }, \text { in }}$

$\dot{E} x_{\text {gain }, \text { solar }}=I_{S} \cdot\left(\frac{100-S E F}{100}\right) \cdot\left(1-F_{f}\right) \cdot A_{w} g$

Solar radiation is shown by $I_{s}\left[\mathrm{~W} / \mathrm{m}^{2}\right], F_{f}$ is the window frame fraction that is taken as $0.3, A_{w}$ is the window area $\left[\mathrm{m}^{2}\right]$ and $g$ is the total transmittance.

$S E F=\left(\frac{t_{\text {shadow }}}{t_{\text {daytime }}} 100\right)$

The Shadow Effect Factor (SEF) is an indication of a building's blockage by the shadow of other objects and buildings [12]. This is the result of the overlapping shadow on the building standing behind another one. The 3D models are used for computing the Shadow Effect Factor (SEF) both for summer and winter periods. In SEF calculation models of the existing situation and the proposed plan are separately developed. These models lets us to simulate the time depended effect of the sun light regarding the attitude of the case are.

SEF is evaluated by determining the ratio of the time under shadow ( $\left.t_{\text {shadow, }}[\mathrm{min}]\right)$ of the building to the daytime $\left(t_{\text {daytime, }}\right.$, [min]) with direct sun light access in an approximate manner by using the 3D model of the area.

$\dot{E} x_{\text {gain }, \text { in }}=n_{o} \cdot \phi_{i, o}+A_{N} \cdot \phi_{i, e}$

where $n_{0}$ is the number of occupants, $A_{N}$ is the floor area of the building $\left[\mathrm{m}^{2}\right], \phi_{i, o}$ and $\phi_{i, e}$ are specific internal gains of occupants [W/occupant] and specific internal gains of equipment $\left[\mathrm{W} / \mathrm{m}^{2}\right]$, respectively.

$\dot{E} x_{\text {input }}$ is calculated by taking $\dot{E} x_{\text {demand }}$ in consideration in addition to the efficiency of the heat production and heat distribution systems, which are used as 0.95 and 0.93 ,respectively.

The exergy flexibility factor shows the possibility of replacing a thermal system by another system especially renewables to meet the exergy demand [6].

$E F F=\frac{\dot{E} x_{\text {demand }}}{\dot{E} x_{\text {input }}}$

$\dot{E} x_{\text {input }}=\frac{\dot{E} x_{\text {demand }}}{\eta_{\text {heat_sys }}}+\dot{E} x_{\text {loss }}+\dot{E} x_{a x u}$

The heat gains of the buildings are also effective on the values of the cooling exergy load of the building. The cooling load of the building is calculated using Eq. (11) that takes the heat gain by auxiliary equipment in the building unit and the energy gain to the building by solar radiation and transmissions from the hot outside to the cooling medium as the inside of the building. The average temperature value is taken as $26.8{ }^{\circ} \mathrm{C}$ [14] for summer season.

$\dot{E} x_{\text {cooling }}=E x_{a x u}+\dot{E} x_{\text {gain,solar }}+\dot{E} x_{\text {gain,transmisson }}$

\section{Case study}

Mavişehir Mass Housing Project is located in the north of Izmir Bay, west of Turkey (Fig. 3). Izmir has hot-humid climate where 
the summers are hot and dry whereas the winters are mild and rainy. July and August are the hottest months with temperatures of $27.3^{\circ} \mathrm{C}$ and $27.6{ }^{\circ} \mathrm{C}$ respectively, the coldest months are January and February with temperatures of $8.6^{\circ} \mathrm{C}$ and $9.6{ }^{\circ} \mathrm{C}$ respectively [14].

According to the data of Çiğli weather station (close to the case area), the prevailing wind direction for the heating period is from southeast, north and northeast. For cooling period, on the other hand, the prevailing mostly arise from the northwest as well as the west and north [20]. When the sun path of Izmir at $12 \mathrm{pm}$ during the year is investigated, the angle of sunlight is found to vary between the edge-case angles of $72^{\circ}-29^{\circ}$.

\subsection{Existing Mavişehir building block}

Mavișehir mass housing area is formed of two sub-regions which were constructed in three stages (Mavişehir I, II, and III). This study covers Mavişehir I and II that can be seen in Fig. 4 in a site plan where various types of buildings are placed as shown. In Mavișehir I, there are 20 residential high-rise buildings (16, 18 and 19 storeys which total to 2784 flats) and 88 duplex villas which are located in between the residential high-rises [11]. Differing from Mavişehir I, Mavişehir II has different types of blocks (10, 14, 20, 22 and 23 storeys) with various designs and combinations of highrises that provide a dynamically built environment. The 3-D representation of the case are is illustrated and shown in Fig. 5 where the positions and heights of the buildings are scaled with respect to the original buildings.

\section{Energy efficient design}

Various parameters such as; physical environmental parameters like temperature, wind, sun path and climate, as well as building scale parameters like orientation, building form, distance between buildings, building organization, building envelope and materials and landscaping are taken into account in design of energy efficient alternatives.

The angle $12^{\circ}$ from south towards east is chosen as the main orientation [19]. Based on the findings of literature, optimum building form is taken as $1: 1.7$ in this study [15]. In the design, width of the building is chosen as $30 \mathrm{~m}$ and length as $18 \mathrm{~m}$. Moreover, the long side of the building faces southward to increase the solar gain.

The optimum building height in this study is selected as $12 \mathrm{~m}$, and to have four-storeys, to strike a balance between compactness and number of housing units. However, to more accurately see the effect of the number of storeys and height of a structure, an alternative building with 8 storeys with a $24 \mathrm{~m}$ height is also studied. Both 4-storey and 8-storey blocks are designed with four units on each storey.

The spacing allowed between the buildings is mainly important when the shadow effect is taken into account. The buildings' shadow must not block another building's solar input. The calculation used with this in mind is based on the sun's radiation angle to the earth. In this calculation, the angular value for the 21st of December is used, as solar radiation's angle is at its lowest in the year at this date. Angular value of $29^{\circ}$ is used in calculations at is at $12: 00 \mathrm{pm}$ that is selected since the maximum radiation occurs at noon. Based on the calculations, the $\mathrm{x} / \mathrm{y}$ ratio must be 0.55 and the maximum shadow length should be 1.96 times the height of building. In this study the ratio of the spacing between the buildings is thus determined to be a rounded " 2 " in order to prevent shadow effect.

To increase the wind's cooling effect on the buildings during the summer and to decrease it during the winter period, the buildings are organized within the building block as shown in Fig. 6 .

Since the aim of this study is to maximize the energy efficiency, the material with the most isolation capability of all material options is selected and used (Table 1).

Four-storey buildings in the first plan and eight-storey buildings in the second site plan are chosen; each have $12 \mathrm{~m}$ and $24 \mathrm{~m}$ 's of height, respectively. As told by Hisarligil [7] for medium storey buildings four and eight-storeys are ideal for energy conservation and efficiency and as such, they are used in the proposed design alternatives in this study.

The existing building blocks were conserved and new design was applied to chosen area.

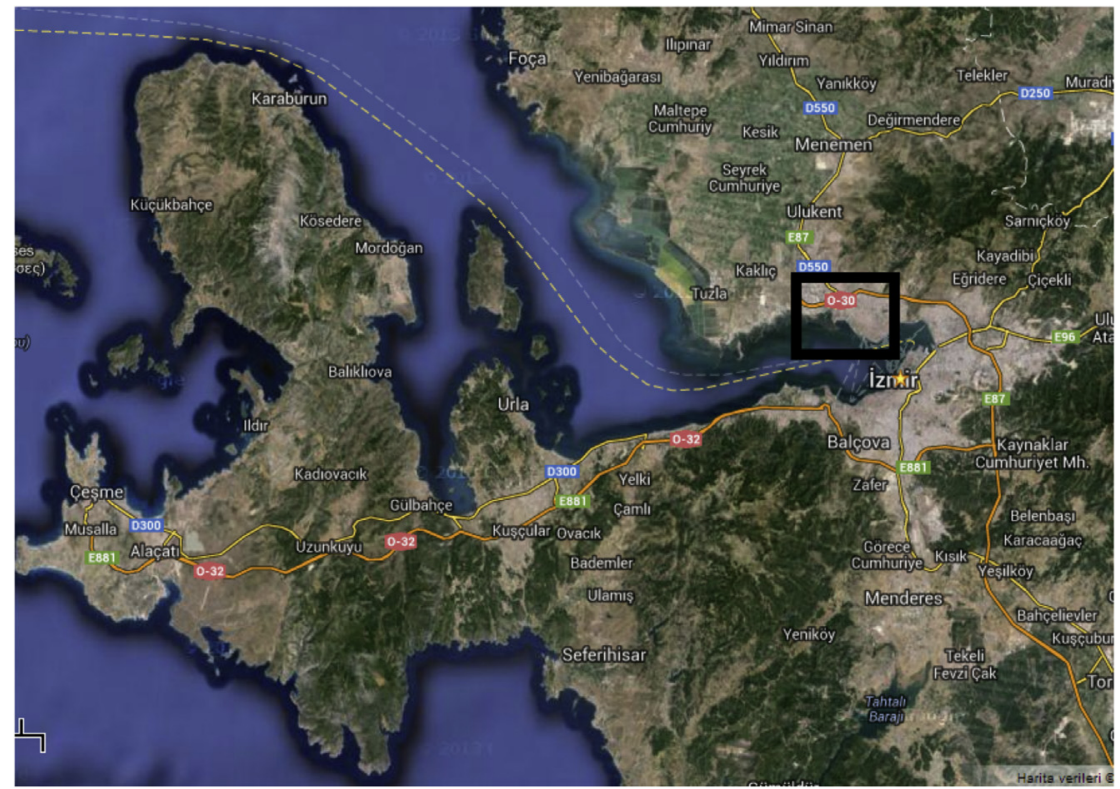

Fig. 3. Location of Mavişehir in Izmir Bay [22]. 


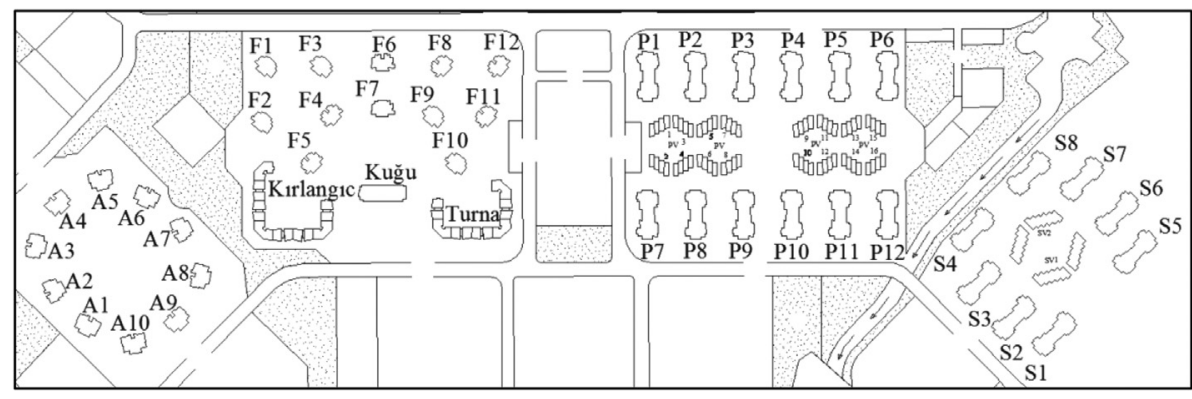

Fig. 4. Site plan of existing building block [9].

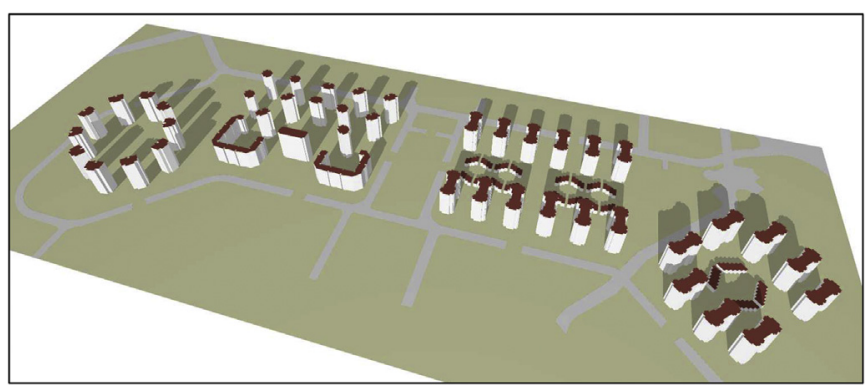

Fig. 5. Site model of existing building block.

\section{Energy efficient alternative site plans}

\subsection{Energy efficient design alternatives: site plan of four-storey building block}

In the four-storey building block, there are 137 separate buildings, and each has 16 housing units. There are a total of 2208 housing units. Green areas, playgrounds, sports area, parking area, social, cultural and educational areas are taken into consideration in the study. The distances between the buildings and orientations of the buildings are arranged according to the energy efficient design parameters. The general and detailed 3-D models of the four-storey plan are shown in Fig. 7, Fig. 8, Fig. 9.

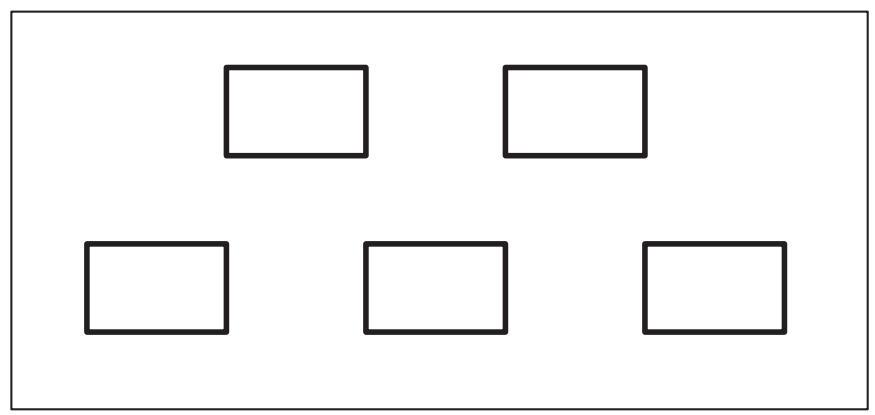

Fig. 6. Organization of the buildings.

Table 1

Heat transfer coefficient values for construction materials of proposed design.

\begin{tabular}{ll}
\hline Building part & Heat transfer coefficient, $\mathrm{U}\left[\mathrm{W} / \mathrm{m}^{2} \mathrm{~K}\right]$ \\
\hline Roof (insulated) & 0.27 \\
Walls (ventilating brick + insulation) & 0.5 \\
Doors, windows (double glazed) & 0.9 \\
\hline
\end{tabular}

\subsection{Energy efficient design alternatives: site plan of eight-storey} building block

In the eight-storey building block, there are 70 separate buildings, and each have 32 housing units for a total of 2240 units. Green areas, playgrounds, sports area, parking area, social, cultural and educational areas were taken into consideration in the study. The site plans of the eight-storey buildings are shown in Fig. 10. Differing from the four-storey plan because of increased building heights, the distance between them is higher. This causes a lower number of buildings in the area -but since the storey number is high, total housing unit count instead increases compared to fourstorey plan.

The general and detailed 3D models of the eight-storey plan are shown in Fig. 11 and Fig. 12. As is the four-storey plan, eight-storey plan also shows that, the distance between buildings and their orientation has a positive effect on the shadow effect. Again the shadows of the buildings are not blocking the other building's solar gain.

\section{Results and discussion}

When the existing plan and the proposed plan alternatives are compared, exergy load value for existing plan is found to be 10 times higher than the new design's. In Fig. 13, the exergy per separate housing unit is shown. It can be perceived that the best value is in eight-storey Plan 1 type housing with $137 \mathrm{~W}$, while in existing plan this value laid in the range of 1800 W. 8 storey Plan 1 's exergy load values are lower than the others, mainly because of general heating system's high performance values in case of high number of housing units. This investigation is carried out per housing unit, since the amount of housing units is different in proposed plan alternatives than the existing situation. Thus, in order to achieve a logical discussion, comparison is applied in a per housing unit basis.

From cooling load's point of view during summer period, the exergy saving is found to be much higher, since the exergy load value decreases from $3181 \mathrm{~W}$ to $616 \mathrm{~W}$ at large (Table 2). This is a result of proper airing, and especially, usage of excellent construction materials (Fig. 13). When the literature values [6] of cooling loads are investigated, it can be seen that cooling loads for hot-humid zones are higher than their heating loads, and the results of this study lie in accordance with the literature.

The amount of saved money and greenhouse emissions is shown in Table 3, per housing unit in the building block. The values show that every housing unit saves 799.54 TL in a year, as an effect of the applied energy efficient design. This is a very considerable and important amount for most of the families in Turkey. More important than money, though, nearly 1.33 tons of greenhouse gas emissions per housing unit also will not be emitted to the 


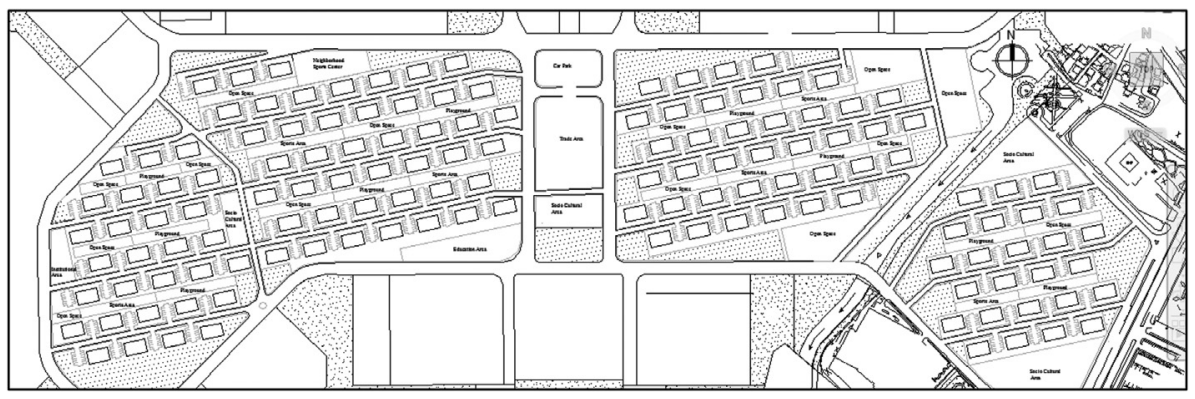

Fig. 7. Site plan of four-storey buildings alternative.

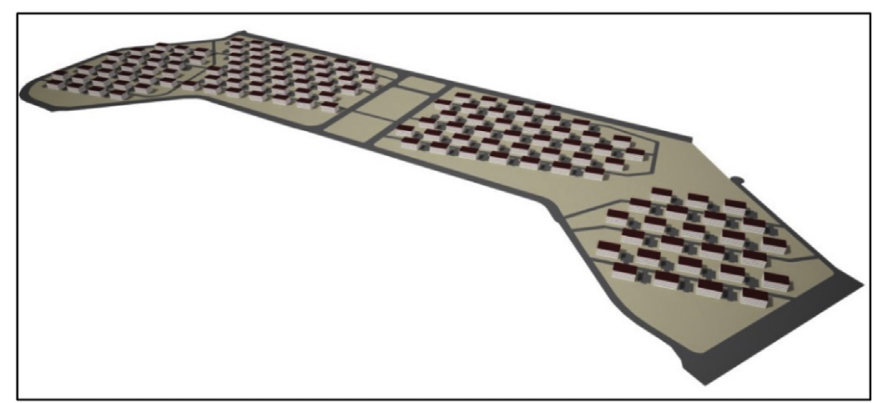

Fig. 8. Site model of four-storey buildings alternative.

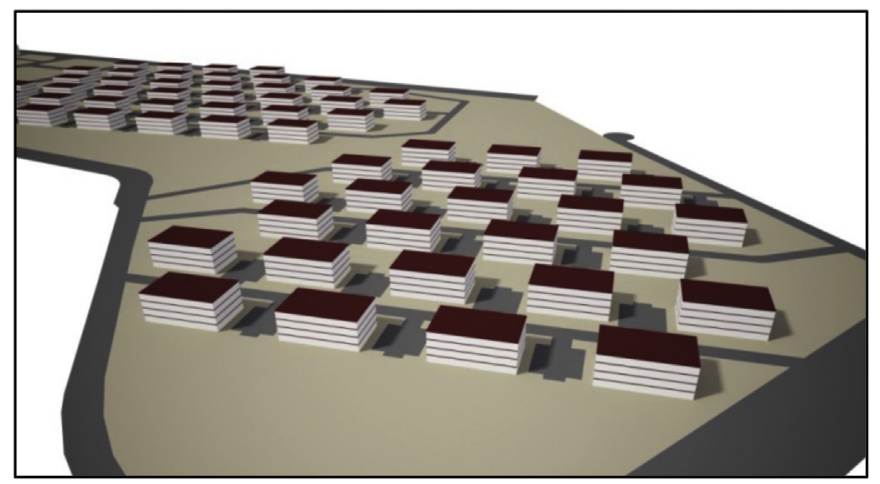

Fig. 9. Detailed site model of four-storey buildings alternative.

atmosphere -which is a magnificent contribution to the environment for sake of a sustainable and green future. These values are calculated using the energy price of $\$ 0.08 / \mathrm{kW}$ for cost, and using reaction stoichiometry calculations with natural gas as fuel in the case area.

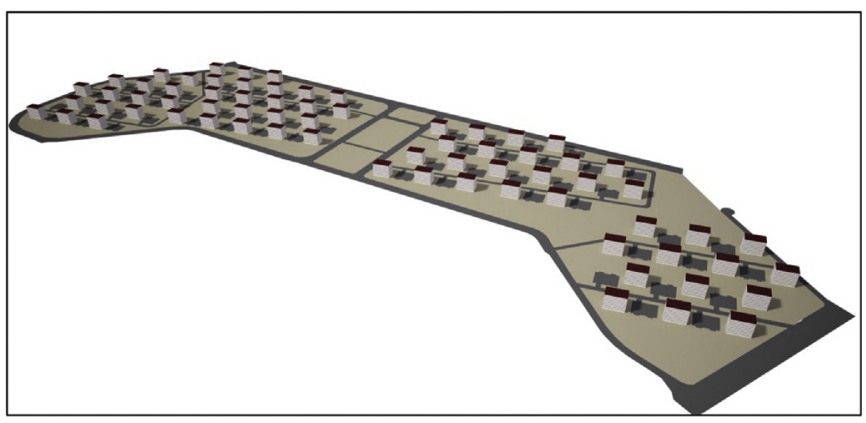

Fig. 11. Site model of four-storey buildings alternative.

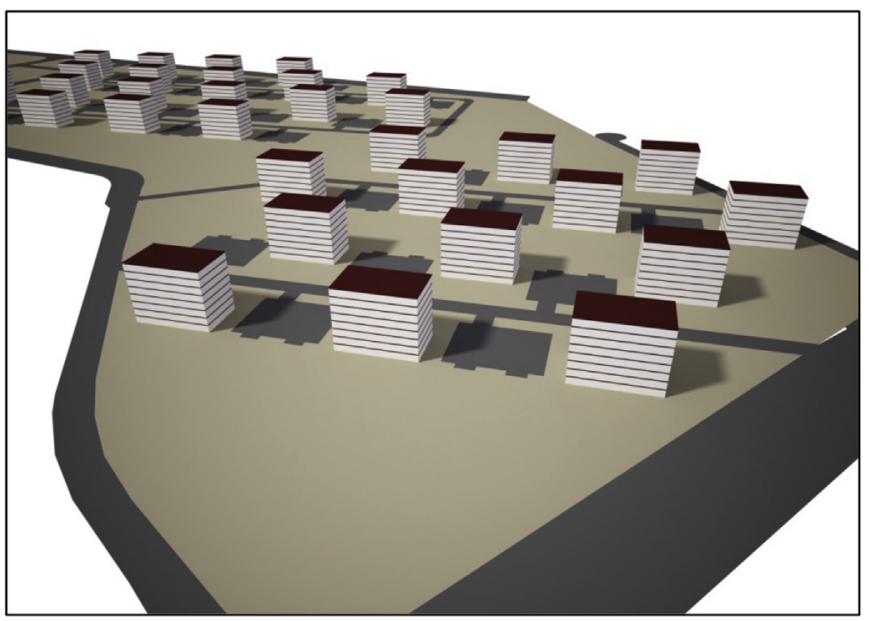

Fig. 12. Detailed site model of four-storey buildings alternative.

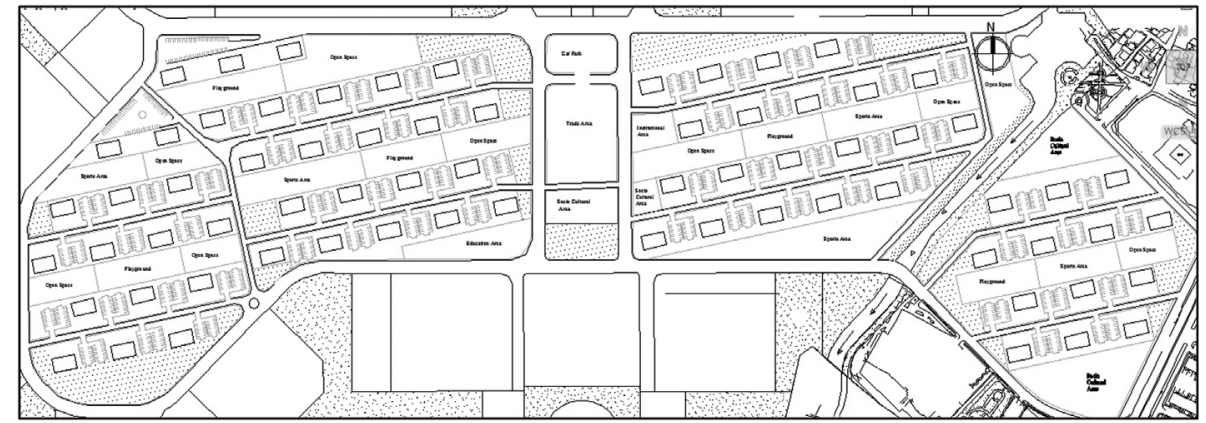

Fig. 10. Site plan of eight-storey buildings alternative. 


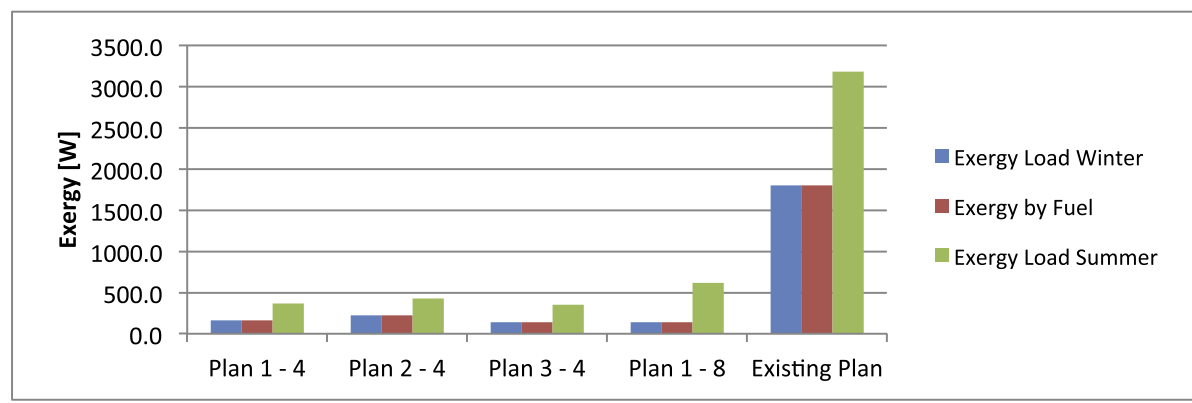

Fig. 13. Exergy load and exergy by fuel values of proposed alternatives and existing plan.

Table 2

Saving by energy efficient design per housing unit.

\begin{tabular}{|c|c|c|c|c|c|}
\hline & \multicolumn{3}{|c|}{ 4-Storey } & \multirow{2}{*}{$\frac{8 \text {-Storey }}{\text { Plan } 1}$} & \multirow[t]{2}{*}{ Existing plan } \\
\hline & Plan 1 & Plan 2 & Plan 3 & & \\
\hline Exergy Load Winter [W] & 166.3 & 225.1 & 142.5 & 137.8 & 1798.0 \\
\hline Exergy by Fuel [w] & 105.4 & 140.0 & 89.9 & 86.3 & 1173.0 \\
\hline Exergy Load Summer [W] & 371 & 428 & 353 & 616 & 3181 \\
\hline
\end{tabular}

Table 3

The annual savings by energy efficient design in Eight-Storey Plan 1.

\begin{tabular}{lc}
\hline Conservation type & Conservation amount (per year) \\
\hline Exergy Winter $[\mathrm{W}]$ & 1631.66 \\
Exergy Summer $[\mathrm{W}]$ & 2810.00 \\
Money [TL] & 799.54 \\
$\mathrm{CO}_{2}$ Emission $[\mathrm{kg}]$ & 1332.56 \\
\hline
\end{tabular}

The exergy calculations are concluded with determinations of exergy efficiency and exergy loads in addition to the annual conservation of exergy, money and greenhouse gases.

In Table 4, general features of the existing building block and the proposed design alternatives are summarized. Each energy efficient design alternative has less housing unit than the existing building block. It is seen that when energy efficient design parameters are taken into account, such as proper distance allocation among the buildings for sunlight purposes, a relatively lower-density building block is needed. In the existing plan, the parking area is also larger than the proposed building block because of the high housing unit count. Moreover, the high housing unit count also causes a decrease in the green open spaces and sports and playground areas.

The housing unit count was decreased in the alternative design proposals. This is a result of increase of the spacing between the buildings for energy efficient design, which naturally creates a lower density in the built area. Also, the monotone structure of the alternative design's plans can easily be observed, but it was neglected in this study since energy efficiency and conservation was aimed, especially by means of increasing solar access of the building blocks.
It can also be figured out that the alternative designs propose larger green areas, open spaces and social areas in comparison to the existing situation in the area. That is also mostly due to the spacing between the buildings.

\section{Conclusion}

In order to increase the energy efficiency in the building block, new design alternatives were proposed. Four different alternatives were generated with three different building plans. Three of them were four-storey, one plan was eight-storey. The results of the exergy analysis of the proposed design alternatives showed that the exergy efficiency values have increased to $12 \%$, from $1.5 \%$ of existing design. The exergy efficiency was increased considerably, and a large amount of energy and money could be conserved through the application of the proposed energy efficient design. The results also show that the annual exergy load of a single housing unit was decreased from $1800 \mathrm{~W}$ to $137 \mathrm{~W}$ for winter and $3180 \mathrm{~W}$ to $346 \mathrm{~W}$ in summer.

As a result of this study, it was found out that by applying an energy efficient design to the selected building block, $1631 \mathrm{~W}$ and $2810 \mathrm{~W}$ of energy could be conserved during the winter and the summer periods for a housing unit, respectively. With this energy conservation, 799.54 TL per housing unit was saved annually, which comes up to $12,792.64$ TL for a block of buildings. More important than that, $1332.56 \mathrm{~kg}$ of emission gases per housing unit, or $21,320.96 \mathrm{~kg}$ for a block of buildings is not going to be released into the atmosphere. This results in the formation of a more sustainable neighborhood. When the total area is taken into account, the exergy efficiency reaches up to $11.23 \%$ while EFF is 29.16 . The Exergy

Table 4

Design values of existing and proposed plan alternatives.

\begin{tabular}{|c|c|c|c|}
\hline & Existing building block & Four-storey building block & Eight-storey building block \\
\hline Number of Building & 155 & 137 & 70 \\
\hline Housing Unit (number) & 5320 & 2192 & 2240 \\
\hline Floor Area of Housing Unit $\left(\mathrm{m}^{2}\right)$ & $56 \mathrm{~m}^{2} \& 150 \mathrm{~m}^{2}$ & $104 \mathrm{~m}^{2} \& 117 \mathrm{~m}^{2}$ & $117 \mathrm{~m}^{2}$ \\
\hline Total Housing Area $\left(\mathbf{m}^{2}\right)$ & 54,135 & 73,980 & 37,800 \\
\hline
\end{tabular}


by Fuel Value is $235.997 \mathrm{~kW}$, with Summer Exergy Load of $652.667 \mathrm{~kW}$ and Winter Exergy Load of $367.287 \mathrm{~kW}$. These are the main indications of the importance of the exergetic analysis in a building block.

In this study, it is concluded that, energy and exergy efficiencies increases considerably when energy efficient design parameters are considered during planning and design steps in an urban area. This encourages us to propose the consideration of these parameters in every construction study starting from design to implementation stages of building blocks and urban areas.

\section{References}

[1] Barreiro EJ, Belausteguigoitia EP, Rodríguez R, Romero A, Turienzo E. City planning and energy efficiency: towards an integrated urban design and planning process. Sustain Dev Plan IV 2009;1:43-51.

[2] Bayındırlık ve İskan Bakanlığı. İklim Değişikliği, Doğal Kaynaklar, Ekolojik Denge, Enerji Verimliliği ve Kentleşme Komisyonu in Komisyon Raporları. 2009 [Ankara].

[3] Canan F. Enerji Etkin Tasarımda Parametrelerin Denetlenmesi Icçin Bir Model Denemesi [Unpublished doctoral dissertation]. Selçuk University; 2008.

[4] EIA (U.S. Energy Information Administration). How much energy is consumed in the world by each sector?. 2013 [accessed 03.11.13], http://www.eia.gov/ tools/faqs,on.

[5] Edwars Brian. Design Challenge of sustainability. In: Castle Helen, Edwards Brian, editors. Green architecture. London: Wiley-Academy; 2001. p. 20-31.

[6] Hepbaşlı Arif. Low exergy (LowEx) heating and cooling systems for sustainable buildings and societies. Renew Sustain Energy Rev 2012:16:73-104.

[7] Hisarlıgil Hakan. Enerji Etkin Planlamada Konut Adası Tasarımı: Hipotetik Konut Adalarının Ankara Orneğinde Mikroklima Analizi [Unpublished doctoral dissertation]. Gazi University; 2009.

[8] Karaca Mehmet. Toplu Konutlarda Enerji Etkinliği; Toplu Konut İdaresi Başkanlığı (TOKI) Toplu Konut Projeleri Üzerinden Bir Inceleme [Unpublished master dissertation]. Gazi University; 2008.

[9] Municapality Karșıyaka. Approved Plan of Mavișehir Mass Housing. Department of Planning Archive; 2012 [accessed on June, 2012]

[10] Mangan Suzi, Dilara, Oral Gül Koçlar. Türkiye'nin Farklı Iklim Bölgelerinde Bir Konut Binasının Enerji Etkin İyileștirilmesi. In: 11.Ulusal Tesisat Mühendisliği Kongresi, Izmir; 2013. p. 921-31.

[11] Mavișehir 1 Administration. 2013. [accessed 03.11.13], www.mavisehir1.com.

[12] Mert Yelda. Application of exergy analysis method to energy efficient building block design [Unpublished doctoral dissertation]. İzmir Institute of Technology; 2014.

[13] Yelda Mert, Saygın Nicel. Exergy analysis of Mass housing areas: Mavisehir I and II, Izmir. Int J Exergy 2014;17:17-34.

[14] MGM (Turkish State Meteorology Service). İklim Sınıflandırması. 2013 [accessed 03.09.13], http://www.mgm.gov.tr/iklim/iklim-siniflandirmalari. aspx?m=IZMIR.

[15] Olgyay Victor. Design with climate-Bioclimatic approach to architectural regionalism. New Jersey: Princeton University Press; 1973.

[16] Ovalı Pınar Kısa. Türkiye İklim Bölgeleri Bağlamında Ekolojik Tasarım Olçütleri Sistematiğinin Oluşturulması- "Kayaköy Yerleşkesinde Orneklenmesi [Unpublished doctoral dissertation]. Trakya University; 2009.
[17] Owens Suzan. Land use planning for energy efficiency. In: Cullingworth B, editor. Energy, land and public policy, energy policy studies, vol. 5. New Jersey: Transaction Publishers; 1990. p. 53-98.

[18] Soysal Seval. Konut Binalarında Tasarım Parametreleri ile Enerji Tüketimi İlişkisi [Unpublished master dissertation]. Gazi University; 2008.

[19] Tokuç Ayça. İzmir'de Enerji Etkin Konut Yapıları İçin Tasarım Kriterleri [Unpublished Master Dissertation]. Dokuz Eylül University; 2005.

[20] Windfinder. Wind \& weather statistics for Izmir-Ciğli. 2013 [accessed 03.11.13], www.windfinder.com.

[21] Dincer I, Rosen M. Exergy: energy, environment, and sustainable development, vol. 1. China.: Elsevier; 2007.

[22] Google Maps, Visualization of Izmir Bay maps.google.com 2013

\section{Nomenclature}

\author{
A: Area $\left(\mathrm{cm}^{2}\right)$ \\ $C_{p}$ : Specific heat $(\mathrm{kJ} / \mathrm{kgK})$ \\ $E_{x}$ : Exergy $(\mathrm{J}, \mathrm{kJ})$ \\ $F_{f}$ : Window frame fraction \\ g: Total transmittance \\ $I_{s}$ : Solar radiation $\left(\mathrm{W} / \mathrm{m}^{2}\right)$, \\ $n$ : Molar flowrate, mole/s \\ $n_{d}$ : Air exchange rate $(\mathrm{ach} / \mathrm{h})$ \\ $n_{0}$ : Number of occupants \\ $n_{v}$ : Efficiency constants \\ $P$ : Pressure, bar \\ $R$ : Gas constant, $\mathrm{J} /$ mole $\mathrm{K}$ \\ $S$ : Entropy, $\mathrm{J} / \mathrm{K}$ \\ $T$ : Temperature (K) \\ $t$ : Time (min) \\ $U$ : Overall heat transfer coefficient $\left(\mathrm{W} / \mathrm{m}^{2} \mathrm{~K}\right)$ \\ $V$ : Volume (m3)
}

Greek Letters

$\eta$ : Efficiency

I,o: Specific internal gains of occupants (W/occupant)

I,e: Specific internal gains of equipment $\left(\mathrm{W} / \mathrm{m}^{2}\right)$

$\rho$ : Density $\left(\mathrm{kg} / \mathrm{m}^{3}\right)$

Subscripts

dest: Destruction

$i$ : Inner, interior

$o$ : Outer, exterior

rev: Reversible

w: Window

ex demand: Exergy need of building

ex loss: Exergy Losses

ex gain: Exergy Gains

Abbreviations

SEF: Shadow Effect Factor

EFF: Energy Flexibility Factor 